\title{
Development of an Attitude Scale towards High School Physics Lessons*
}

\author{
Pervin Ünlü Yavaş ${ }^{1}$, Sultan Çağan ${ }^{2}$ \\ ${ }^{1}$ Gazi Faculty of Education, Gazi University, Ankara, Turkey \\ ${ }^{2}$ Kalecik Mehmet Doğan Science High School, Ankara, Turkey \\ Correspondence: Pervin Ünlü Yavaş, Gazi Faculty of Education, Physics Education Department, Ankara, Turkey.
}

Received: November 10, 2016

Accepted: December 5, 2016 Online Published: December 11, 2016

doi:10.11114/jets.v5i1.1974

URL: http://dx.doi.org/10.11114/jets.v5i1.1974

*This study was developed from the second author's thesis.

\begin{abstract}
The aim of this study was to develop a Likert type attitude scale for high school students with regard to high school physics lessons. The research was carried out with high school students who were studying in Ankara. First, the opinions of 105 high school students about physics lessons were obtained and then 55 scale items were determined from these opinions. Expert opinions were sought for the language and content validity of these items. In line with the expert opinions some items were corrected and some were taken out of the scale. The draft scale, which had 44 items, was tested on 698 high school students. The factor structure of the scale was ascertained by carrying out exploratory factor analysis from the data that were gathered. The variance of the scale, which consists of 28 items and 4 factors (interest, anxiety, importance, and self-efficacy), was $60 \%$. The consistent between the model and the scale data was observed by carrying out confirmatory factor analysis. Since the fit indices of the scale ensure the acceptability criteria, it was observed that the factor model is appropriate. The Cronbach-alpha reliability coefficients of the factors of the scale developed were calculated and it was decided that the scale is reliable.
\end{abstract}

Keywords: physics lessons, attitude scale, scale development, high school students

\section{Introduction}

The vision of the 2007 Physics Curriculum in Turkey was to educate individuals who have internalized physics as fundamental to life itself, who can solve problems they encounter by using scientific methods, who can analyze the interactions between 'Physics, Technology, Society and the Environment', who have developed positive attitudes and behaviors towards themselves and the environment, who possess the skills for information literacy which are required by the information society, who can express their opinions objectively and in the most efficient way, who are at ease with themselves and in harmony with their environment, and who are productive (Ministry of National Education [MoNE], 2007). From this vision it can be inferred that to learn physics should not just be an issue that concerns only one part of society. In fact, the Physics Curriculum was updated in 2013 and physics lessons, which were only previously obligatory for 9th grade students, were also made obligatory for 10th grade students. It is emphasized in the 'affective principles' of the 2013 Physics Curriculum that students' beliefs about whether or not they will be able to learn physics have a great effect on learning physics (MoNE, 2013). As in other fields, in science teaching too the most important affective areas are attitude and motivation. Science teaching, which not only engages the cognitive faculties of the students but also engages their affective qualities, has an important role in improving students' attitudes towards science and in enhancing their motivation to learn science (Huyugüzel Çavaş \& Çavaş, 2014).

In measuring attitudes while teaching science Reid (2006) speaks of four objectives within, respectively, the subject of science, learning science, a topic or a theme within lessons, and methods within the subject of science. Among these objectives the one most studied is the attitudes towards the subject of science (Kaya, 2012; Kind, Jones \& Barmby, 2007; Krough \& Thomson, 2005; Osborne, Simon \& Collins, 2003; Pell \& Jarvis, 2001; Reid \& Skryabina, 2002; Şentürk \& Özdemir, 2014). In these studies, attitudes towards science lessons were viewed as a sub-dimension of attitudes towards the subject of science. There are also researches in which only the attitudes of students towards science lessons were investigated. What is meant here by science lessons are either general science, or specific physics, chemistry and biology lessons. The studies of Nuhoğlu (2008), Shah and Mahmood (2011) can be given as examples of projects in which the attitudes towards science lessons are investigated; the analyses of Bennett (2001), Hançer, Uludağ 
and Yılmaz (2007), Kan and Akbaş (2005) can be given as examples of works which research attitudes towards chemistry lesson; the studies of Atik, Kayabaşı, Yağcı and Erkoç (2015), Ekici and Hevedanlı (2010), Koçakoğlu and Türkmen (2010), Pehlivan and Köseoğlu (2010) and Prokop, Tuncer and Cluda (2007) can be given as examples of projects in which attitudes towards biology lesson are researched, and the works of Demirci (2004), Kaya and Böyük (2011), Kurnaz and Yiğit, (2010), Özyürek and Eryılmaz (2001) and Tekbıyık and Akdeniz (2010) can be given as examples of ideas which investigate attitudes towards physics lesson. There are a number of studies that have researched the effects of a hypothesis, an approach, a method, a model or specific teaching activities on the attitudes of the students (Azar, Presley \& Balkaya, 2006; Baran, 2009; Bilgin, 2006; Bozkurt \& Aydoğdu, 2009; Korucuoğlu, 2008; Orçan, 2013; Taş, 2015; Türer \& Kunt, 2015; Zacharia, 2003). The fact that there are a lot of such studies reveals the need for attitude scales.

In Turkey, some researches of attitude scale development and adaptation have been carried out with regard to physics lessons and subjects. An attitude scale aimed at introductory physics lessons was developed by Demirci (2004) and an attitude scale for lessons in introductory optics was developed by Kaya Şengören, Tanel and Kavcar (2006) for university students. From among the scale development studies carried out for high school students, Tekbiylk and Akdeniz (2010) can be considered as an attitude scale aimed at physics Kurnaz and Yiğit (2010) can be considered as an attitude scale aimed at physics, subjects related to physics and the studies that are carried out within these, and Taşlidere and Eryılmaz (2012a) can be considered as an attitude scale aimed at the topic of simple electric circuits. Scale adaptation studies have also been carried out for high school students. Akyüz (2004) adapted attitude scales for the topic of heat and temperature; Kaya and Böyük (2011) adapted attitude scales towards physics lesson and physics experiments, and Taşlıdere and Eryılmaz (2012b) adapted attitude scales for optics lessons.

The aim of this study was to develop an attitude scale for students with regard to high school physics lessons. The content of the scale developed is important since it is different from the above-mentioned scales and can therefore be put to use by researchers as an alternative tool.

\section{Method}

The process of developing the attitude scale towards physics lessons consisted of four stages. These were: item-writing and creating a draft form, pre-practice studies, the practice stage and the analysis stage. These stages are discussed respectively below.

\subsection{Item-writing and Creating a Draft Form}

First, it was decided that the scale would be a Likert-type scale. To create the items for the Likert scale, 105 students studying in the 9th, 10th, 11th and 12th grades in an Anatolian high school in Ankara were asked to write sentences expressing their feelings and opinions with regard to physics lessons. Those sentences which could be used as an attitudinal item were determined by examining these writings and 55 scale items were created. While developing the items attention was paid to ensure that each item was written in simple language and was clear, that the sentences were not too long, and that each item only included one feeling or opinion. When scale items that had been used in the previous literature were examined it was seen that some of the items were extremely similar to the items obtained from the students' writings (e.g. I like it, I get bored etc.) and that some of the items were aimed at university students. Hence no item was added to the item pool from the literature. In this way it was ensured that the factors which were going to be developed in the study were authentic. It was determined that the scale would consist of five grades. The gradations were "Strongly agree", "Agree", "Neutral", "Disagree" and "Strongly disagree", and a draft form was subsequently created.

\subsection{Pre-practice Studies}

To ensure the comprehensibility of these items in terms of language, the expert opinions of two Turkish language teachers were obtained, and for their appropriateness in terms of measuring the attitudes towards physics lesson, the expert opinions of three physics teachers and two physics education lecturers were obtained. Some items were corrected in line with the expert opinions and it was decided to take some items out of the scale. With the aim of determining the students' comprehension of the 44 items that remained after the expert opinions, opinions were obtained from three students with high, medium and low achievement levels respectively, according to their physics exam results. The opinion of the lesson teacher was obtained as a basis for determining the success levels of the students. Each student was interviewed separately and they were asked how they understood each item. It was found that the students understood the items no differently than how they were meant to be understood.

Out of the items remaining in the item pool, 24 of the items were positive and 20 were negative. In the first part of the scale a space was created in which the students could write their demographic information. Gradation checkboxes were placed across these items. The draft scale was thus complete, and multiple hard copies were then made. In order to 
determine the students' response time for the scale, the scale was practiced on 30 students and the response time was determined to be 20 minutes. However, to allow the students to answer all the questions on the scale, no rigid practices were enforced in terms of response times.

\subsection{Practice Stage}

The item pool development stage was carried out with students who were studying in an Anatolian high school in Ankara. It was decided that the population of the research should consist of students studying in Anatolian high schools in Ankara. The sample was created according to the maximum variation sampling method so that it could best represent the province of Ankara. In the responding stage of the scale some parts of the implementation were managed in person by the teacher who was carrying out the research. The management of the other test, however, was given to the teachers of the classes in which they were going to be performed. Whether the teachers would carry out the test properly with regard to the method was instrumental in selecting the classes to make up the sample. The sample of the research consisted of students who were studying in the 9th, 10th, 11th and 12th grades of Anatolian high schools in six different areas of Ankara. The draft scale was practiced on 845 students. Some students were found to have answered questions without reading them, or were leaving too many questions blank; therefore the data from 147 students were excluded from the analysis. The distribution of the students by classes is shown on Table 1

Table 1. The distribution of the students who participated in the analysis with reference to their classes

\begin{tabular}{cc}
\hline Class/Age & Number of Students \\
\hline $9 / 14$ & 92 \\
$10 / 15$ & 396 \\
$11 / 16$ & 186 \\
$12 / 17$ & 24 \\
Total & 698
\end{tabular}

Since they were preparing for matriculation, an adequate number of twelfth grade students could not be found. A major part of the data excluded from the analysis consisted of that from ninth grade students.

\subsection{Analysis Stage}

The analysis of the data that were gathered following the implementation of the scale was carried out by exploratory and confirmatory factor analyses. The purpose of using exploratory factor analysis is to determine the implicit structure of the scale, and the purpose of using the confirmatory factor analysis is to verify the determined implicit structure (Seçer, 2015). In the exploratory factor analysis the factor structure of the scale is ascertained and the construct validity is viewed. In confirmatory factor analysis the construct validity is viewed with the verification of the previously determined scale factor structure (Büyüköztürk, Çakmak, Akgün, Karadeniz \& Demirel, 2009). Exploratory factor analysis is used for the reliability of the scale, whereas confirmatory factor analysis is used for the reliability of the model (Şencan, 2005). The analysis was completed by calculating the reliability for the scale after factor analyses were completed.

\subsubsection{Exploratory Factor Analysis}

Exploratory factor analysis helps the researcher to understand the relations between the concepts used within the data set by revealing the basic factors (relation structure) that belong to a data set which consists of a great number of variables that are related to each other (Coşkun, Altunışık, Bayraktaroğlu \& Yıldırım, 2015).

To determine the factor structure of the scale, the data gathered from the implementation of the scale were analyzed by SPSS packaged software. The positive items which were used in the scale were graded as follows: Strongly agree (5 points), agree (4 points), neutral ( 3 points), disagree ( 2 points) and strongly disagree (1 point). However, the negative items were graded as strongly agree (1 point) and strongly disagree (5 points).

Whereas it is generally agreed that the use of larger samples in the conduct of factor analysis provides more precise and stable estimates of factor loadings in the population, there is little agreement as to how large a sample must be to yield such estimates (Hogarty, Hines, Kromrey, Ferron \& Mumfor, 2005). Comrey and Lee (1973) described the size of a sample as follows: $100=$ poor, $200=$ appropriate, $300=$ good, $400=$ very good, 1000 and more=perfect. Catell (1978), on the other hand, proposed that the size of a sample should be determined in regard to the number of the items, and the sample number/item number (N/p) rate should be from 3:1 to 6:1. Everitt (1975) proposed that this rate should be 10:1 and Hair, Anderson, Tatham and Balack (1995) proposed that this rate should be 20:1 (quoted by Hogarty, Hines, Kromrey, Ferron \& Mumfor, 2005). In the estimation of the factor analysis it has been proposed that the size of a 
sample should reach a size sufficient to answer at least two of the criteria used in the literature (Çokluk, Şekercioğlu \& Büyüköztürk, 2014). Since the sample of this study consisted of 698 individuals, it was large enough to cover at least two of these criteria.

The Kaiser-Meyer-Olkin (KMO) test and Bartlett's Test of Sphericity measure of sampling adequacy was used to examine the appropriateness of factor analysis. The KMO test is the measure of sampling adequacy, which varies between 0 and 1 . When this value comes out high it means that each and every variable in the scale can be estimated perfectly by the other variables in the scale. If the test result is bigger than 0.5 , the factor analysis can be continued (Sencan, 2005, p.384). Kaiser (1974) stated that if that value is lower than 0.5 it is not acceptable, if it is in the 0.5 's it is miserable, in the 0.6 's it is mediocre, in the 0.7 's it is middling, in the 0.8 's it is meritorious, and in the 0.9 's it is marvelous. The KMO value attained from the present study is 0.953 and it is marvelous. The Bartlett's Test gives the value of the chi-square statistics. As is in other chi-square tests, in this test the search is for the significance value. If the significance value is lower than 0.05 , it means that the factor analysis can be carried out (Şencan, 2005). On the other hand, the Bartlett's Test results of this study revealed that the chi-square value was significant $\left(X_{(378)}^{2}=11339.067 ; p<.001\right)$. These values show that factor analysis can be continued to develop the scale.

Some criteria are used in the determination of the appropriate factor numbers for the scale to be developed. These are the eigenvalue, total variance explained and scree plot graphic, which is created based upon the eigenvalues of the factors (Büyüköztürk, 2002). The eigenvalue criterion is widely used, factors which have an eigenvalue of bigger than 1 are determined (Özdamar, 2016). The other criterion takes into consideration the variance rate explained by the factors. For example, if the load of a factor is 0.3 , it shows that the explained variance is $9 \%$. In determining the factor number, the explained variance rate is asked to cover $2 / 3$ of the total variance (Büyüköztürk, 2002). The factor number is determined by lowering this rate to $60 \%$ in social and educational sciences and even to $50 \%$ in some research (Özdamar, 2016). The examination of the scree plot graphic is the last criterion in deciding the factor number. This graphic helps the factors to decrease by showing the dominant factors. In the graphic, the vertical axis shows the eigenvalues and the horizontal axis shows the factors, and the factor in which there are rapid declines shows the number of important factors (Çokluk et al., 2014). There are also other criteria in deciding the factor numbers (Şencan, 2005, Özdamar, 2016). However, the above-mentioned three criteria are used in this study.

In factor analysis the items which do not measure the same structure are eliminated. The loadings of the factors in which the items take place should be high. It is suggested that the factor load value should be 0.45 or higher but in practice the limit values can be as low as 0.30 (Büyüköztürk, 2016). The factor loadings in this study was considered to be $>0.40$. Another criterion in the elimination of items is that the item has a high value in one factor and low load values in other factors. It is suggested that except for the high load value an item gives to a factor, the difference between the load values it gives to another factor should be at least 0.10. In a multi-factor structure, the item which gives high load values to more than one factor is defined as a cross-loading item and it is appropriate to exclude this item from the scale (Büyüköztürk, 2016).

Rotation operations are used so that the solution can be interpreted after factorizing and so that scientific benefits can be improved (Çokluk et al., 2014). There are innumerable methods of rotation, but the most commonly used method is varimax. The aim of varimax rotation is to bring out the factor load variances at the uppermost by making the high ones higher for each factor and the low ones lower (Tabachnick \& Fidell, 2013). The varimax rotation operation was used in this study.

\subsubsection{Confirmatory Factor Analysis}

Confirmatory factor analysis gives information about the validity of the model and the factor structure. In this analysis the point is to prove the relations between the factors and the variables and the relations the factors have within themselves. The attempt is made to define whether the model, which has been determined according to the previous research results or theoretical knowledge, is verified or not by the observation data or to what extent the model and the observation data accord with each other. Unlike exploratory factor analysis, the measurement values are appointed or fixed to certain factors beforehand (Şencan, 2005). The consistent between the factor model and the observation data which was attained with the exploratory factor model in this study was examined with confirmatory factor analysis. The analyses were carried out by LISREL packaged software. The analysis starts with the drawing of a graphic which is called the path diagram. The rectangles in the graphic show the observed variables which are the scale items and the ovals show the hidden variables which are the factors. In the exploratory factor analysis there is no limitation; that is, it allows the items which occur in the measurement instrument to have relations with all the factors. However, in the confirmatory factor analysis each and every factor and the items corresponding to these factors are defined and limited (Kline, 2011). The two-arrowed curved lines which show the relations between the factors represent the correlation between the factors. The correlation between the factors should not be bigger than 0.85 . 
A series of statistical value is attained that shows to what extent the model, which is created as a result of the results of the computer analyses, complies with the data structure. The most basic statistical value is the chi-square/degree of freedom $\left(x^{2} / d f\right)$ rate. The chi-square value is should be small but since it is responsive to the size of the sample, in many cases uncertainties arise about this, stemming from whether the statistics are significant because of poor model fit or because of the inadequacy of the sample size. Different statistical techniques have been developed because of these uncertainties (Şencan, 2005). These parameters which show the model's accordance to the data structure are called fit indices. Fit indices and acceptance criteria will be discussed in the findings section along with the results of the research. If the fit indices do not meet the acceptable model fit it will be hard to redefine the model. In this case suggestions for modifications, which have emerged as a result of the analysis, will be examined (Çokluk et al., 2014).

\subsubsection{Reliability}

It is appropriate to use the alpha coefficient, which was developed by Cronbach and is a criterion for internal consistency, in determining the level of reliability in a Likert attitude scale. The scales which consist of items that show strong relations with each other have a high alpha coefficient. The higher the alpha coefficient of the scale is, the more consistent the items which take place in the scale are with each other and it shows that they consist of items which measure the factors of the same feature (Tavşanc1l, 2014). For this reason the Cronbach-alpha internal consistency coefficients of the factors, which took their final forms by factor analysis, are calculated. Reliability analyses are performed separately for each dimension by taking their factor structures into consideration (Şencan, 2005). The evaluation of the size of the reliability coefficient for a scale in educational and social sciences is as following: $\alpha<0.40$ not reliable, $0.40<\alpha<0.50$ low-level reliable, $0.50<\alpha<0.60$ medium-level reliable, $0.60<\alpha<0.75$ reliable in the generally accepted, $0.60<\alpha<0.75$ highly reliable, $\alpha \geq$ reliable to a perfect level (Özdamar, 2016).

\section{Results}

\subsection{Results of the Exploratory Factor Analysis}

It was explained in the methods section that it was necessary to determine that the data were in accordance with the analysis to perform an exploratory factor analysis. In order to determine that the data were in accordance with the analysis, the KMO and the Bartlett's test results were consulted. The fact that KMO value is 0.953 and the Bartlett's test result was $\chi_{(378)}^{2}=11339.067 ; p<.001$ showed that the factor analysis can continue to be carried out.

For the factor analysis, the eigenvalues and the communalities of the items were first of all calculated. The items were gathered under 6 factors whose eigenvalues are bigger than 1 . These 6 factors explained $62.588 \%$ of the total variance. After taking into consideration the factors whose eigenvalues were bigger than 1, the next criterion in determining the factor number was examined, which is the scree plot graphic. The scree plot graphic is given in Figure 1.

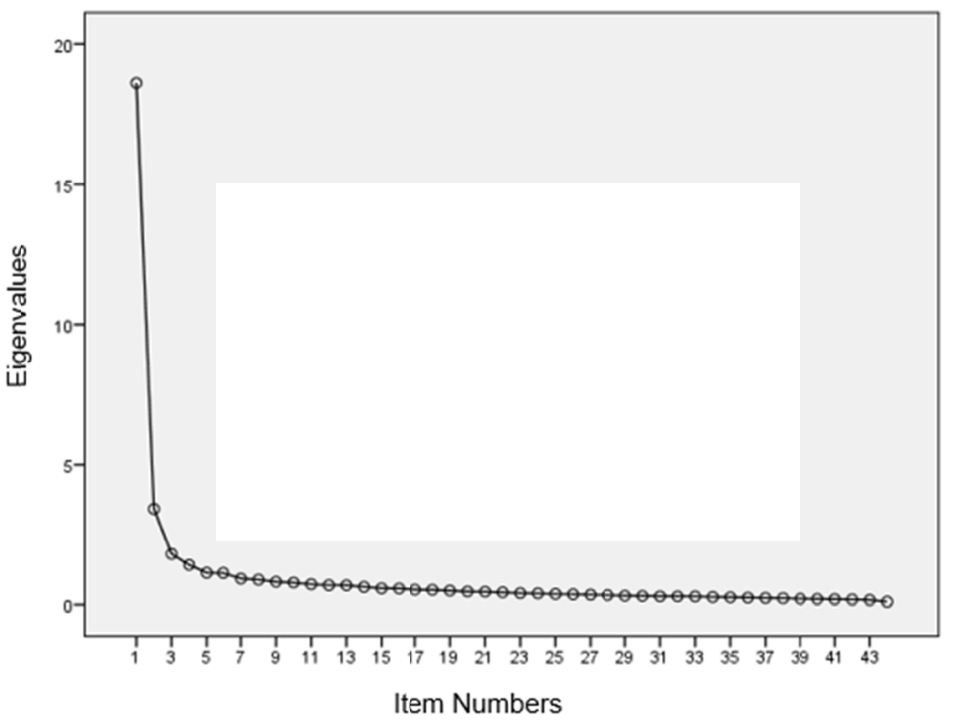

Figure 1. Scree Plot Graphic

When the graphic is viewed it is seen that after the fifth point the general tendency of the graphic is horizontal and it does not show a significant decline, and the contributions of the fifth and other factors to the variance are close to each other. For this reason it was decided that the number of factors would be 4 . The fact that it is appropriate for the items which occur in the scale to be gathered under 4 factors was theoretically estimated beforehand. The factor number 
which was determined as a result of the analysis was the same as the number previously estimated. It can be seen that the factor loadings of the items were between 0.347 and 0.810 . The four items whose factor load values remained under 0.4 (items number 7, 26, 35 and 43) were excluded from the scale. Varimax rotation was performed to investigate the distribution of the remaining 40 items to the factors. After rotation, 12 items (items number 1, 10, 13, 14, 15, 21, 22, 24, 28, 34, 39 and 42) were excluded from the scale because they were cyclical items since they had less than 0.1 differences between the loads they gave to more than one factor. The eigenvalues, the variance percentages and the total variance percentages of the remaining 28 items are shown in Table 1.

Table 2. Total Variance Explained

\begin{tabular}{crcr}
\hline Factor & Eigenvalues & \% of Variance & Cumulative \% \\
\hline 1 & 11.406 & 40.736 & 40.736 \\
2 & 2.865 & 10.231 & 50.967 \\
3 & 1.425 & 5.089 & 56.056 \\
4 & 1.229 & 4.389 & 60.445
\end{tabular}

The variance explained by the four factors constituted $60 \%$ of the total variance. According to Streiner (1994) the variance that remaining factors explain should be over $50 \%$. The total variance rate which the factors of the developed scale explain was higher than this limit value.

The factor pattern, the factor loadings of the items and the communalities that were attained as a result of the analysis are shown in Table 2.

Table 3. The Factor Pattern of the Attitude Scale towards Physics Lessons

\begin{tabular}{|c|c|c|c|c|c|}
\hline \multirow{2}{*}{ Item No } & \multicolumn{4}{|c|}{ Factor Loading } & \multirow{2}{*}{ Communalities } \\
\hline & 1 & 2 & 3 & 4 & \\
\hline 44 & 0.724 & 0.90 & 0.217 & 0.166 & 0.61 \\
\hline 2 & 0.705 & 0.181 & 0.222 & 0.097 & 0.59 \\
\hline 18 & 0.704 & 0.203 & 0.173 & 0.147 & 0.59 \\
\hline 32 & 0.671 & 0.014 & 0.168 & 0.086 & 0.49 \\
\hline 16 & 0.670 & 0.166 & 0.330 & 0.185 & 0.62 \\
\hline 4 & 0.661 & -0.017 & 0.231 & 0.209 & 0.53 \\
\hline 12 & 0.642 & 0.250 & 0.424 & 0.149 & 0.68 \\
\hline 37 & 0.639 & 0.121 & 0.022 & 0.105 & 0.43 \\
\hline 30 & 0.623 & 0.221 & 0.446 & 0.177 & 0.67 \\
\hline 29 & 0.434 & 0.230 & 0.277 & -0.181 & 0.35 \\
\hline 36 & 0.198 & 0.779 & 0.216 & 0.144 & 0.71 \\
\hline 25 & 0.204 & 0.765 & 0.297 & 0.195 & 0.75 \\
\hline 17 & 0.198 & 0.755 & 0.241 & 0.194 & 0.70 \\
\hline 5 & 0.116 & 0.707 & 0.151 & 0.232 & 0.59 \\
\hline 40 & -0.40 & 0.6970 & -0.237 & -0.150 & 0.72 \\
\hline 38 & 0.190 & 0.695 & 0.291 & 0.156 & 0.63 \\
\hline 33 & 0.138 & 0.657 & 0.414 & 0.139 & 0.64 \\
\hline 19 & 0.138 & 0.646 & 0.326 & 0.276 & 0.62 \\
\hline 41 & 0.202 & 0.327 & 0.715 & 0.076 & 0.66 \\
\hline 27 & 0.326 & 0.143 & 0.710 & 0.088 & 0.64 \\
\hline 20 & 0.420 & 0.270 & 0.648 & 0.170 & 0.70 \\
\hline 43 & 0.337 & 0.093 & 0.641 & 0.095 & 0.54 \\
\hline 31 & 0.446 & 0.255 & 0.636 & 0.034 & 0.67 \\
\hline 14 & 0.174 & 0.261 & 0.618 & 0.231 & 0.53 \\
\hline 8 & 0.068 & 0.176 & 0.178 & 0.743 & 0.62 \\
\hline 6 & 0.189 & 0.155 & 0.269 & 0.706 & 0.63 \\
\hline 9 & 0.303 & 0.438 & 0.203 & 0.570 & 0.65 \\
\hline 23 & 0.260 & 0.139 & -0.109 & 0.483 & 0.33 \\
\hline
\end{tabular}

As seen on Table 2, the load values of the first factor are between 0.724 and 0.434 for the first factor, 0.779 and 0.646 for the second factor, 0.715 and 0.618 for the third factor, and 0.743 and 0.483 for the fourth factor. Comrey and Lee (1992) suggested that loads exceeding 0.71 (50\% overlapping variance) should be qualified as perfect $0.63(40 \%$ overlapping variance) as very good, 0.55 (30\% overlapping variance) as good, 0.45 ( $20 \%$ overlapping variance) as reasonable and 0.32 (10\% overlapping variance) as poor (quoted by Tabachnick and Fidell, 2013). According to this evaluation, the factor loads of the scale developed were generally accepted as perfect and very good, but the load values of items number 23 and 29 were accepted to be reasonable. The last column of Table 2 shows the communalities. The communalities variance takes readings between 0 and 1 . If the communalities is closer to 1 for an item it means that the 
indicator contributes to the variance to a high extent, but if it is closer to 0 then it means that the indicator contributes to the variance to a low extent (Çokluk et al., 2014). If the communalities is lower than 0.20 then that item is excluded from the scale and the analysis has to be performed once again (Şencan, 2005). It can be seen that the communalities of items on Table 2 have readings between 0.75 and 0.33 . There were no problematic items in terms of communalities.

The factors were named after the completion of the analysis. The factors were named by examining the items that had been placed in the factors. The names given to the items which had a similar content to those found in the literature were examined while labeling the factors. The items in the first factor consisted of statements about physics lessons such as "I like them, I think they are boring, I want to learn". This factor was named "interest". The items in the second factor consisted of statements about physics lessons such as worry, fear, playing truant, so this factor was named "anxiety". The items in the third factor consisted of statements about physics lessons expressing that they are unnecessary, or related to everyday life, or a waste of time, so this factor was named "importance". The items in the fourth factor consisted of statements about physics lessons such as "I know; I can understand them" which had meanings relevant to self-confidence, so this factor was named "self-efficacy". The categorizing of the interest, importance and self-efficacy factors was inspired by the studies of Taşlidere and Eryılmaz (2012a).

\subsection{Results of Confirmatory Factor Analysis}

The factor model, which consisted of the 28 items and 4 factors attained by exploratory factor analysis and its consistent with the data structure, was examined by confirmatory factor analysis. The confirmatory factor analysis was carried out with the LISREL packaged software. The items that belonged to the factors attained by exploratory factor analysis were identified in the LISREL packaged software and a path diagram was drawn. When we look at the fit indices that were calculated for the appropriateness of the model we see that the value of $x^{2} / d f$ was 4.66 and that it provided for the agreed value. In the case of ideal fit this value is expected to be 2 or less. On the other hand an $x^{2} / d f$ value which is between 2 and 5 shows acceptable thresholds (Özdamar, 2016, p. 185). The modifications suggested by the analysis were applied at this stage and there was a minor improvement in the fit indices. The first analysis and the fit indices after the modification can be seen in Table 4.

Table 4. The fit indices of the model for the confirmatory factor analysis

\begin{tabular}{lllllll}
\hline Analysis & $\boldsymbol{x}^{\mathbf{2}}$ & $\boldsymbol{x}^{\mathbf{2}} / d f$ & RMSEA & RMR & GFI & AGFI \\
\hline First & 147 & 4.29 & 0.072 & 0.095 & 0.86 & 0.84 \\
& 4.7 & & & & & 0.85 \\
Last & 144 & 4.22 & 0.068 & 0.094 & 0.87 &
\end{tabular}

From the fit indices, GFI and AGFI should be over 0.90, and RMR and RMSEA should be under 0.50. The following criteria can also be accepted in the evaluation of the fit of the model: GFI $>0.85$, AGFI $>0.80$, RMR and RMSEA $<0.10$ (Çokluk et al., 2014). It can be seen that the fit indices given in Table 4 provide for the acceptance boundary. These findings show that the model was in consistent with the data structure. The path diagram belonging to the confirmatory factor analysis is seen in Figure 2. The standardized coefficients which show the relations of the items and the factors to which they belong vary between 0.37 and 0.86 . Figure 2 shows the correlation coefficients between the factors.

The correlations of the factors with each other are as following: $r_{\text {interest-anxiety }}=0.58 ; r_{\text {interest-importance }}=0.84$; $\mathrm{r}_{\text {interest-self-efficacy }}=0.67 ; \mathrm{r}_{\text {anxiety-importance }}=0.68 ; \mathrm{r}_{\text {anxiety-self-efficacy }}=0.73 ; \mathrm{r}_{\text {importance-self-efficacy }}=0.61$. 


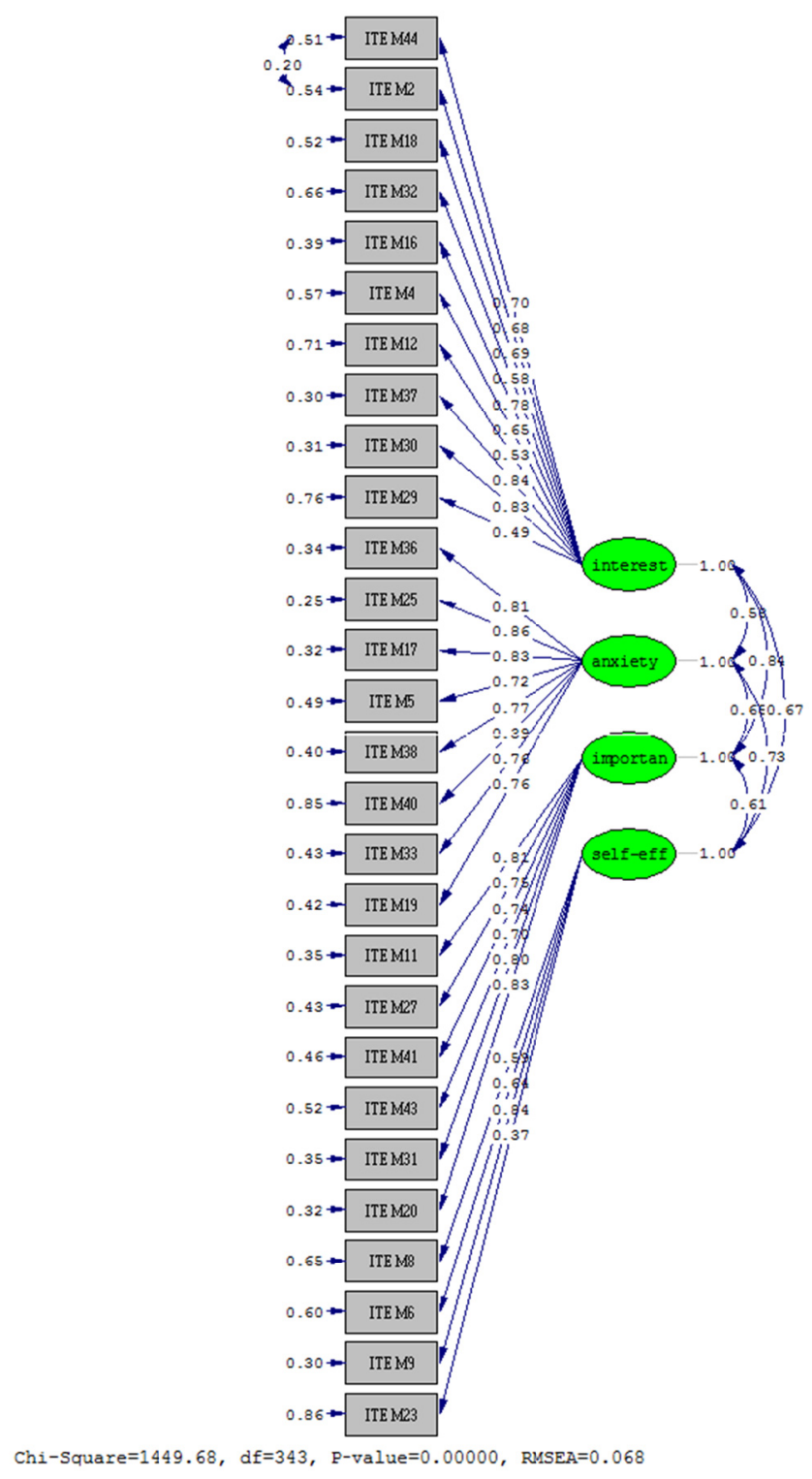

Figure 2. The Confirmatory Factor Analysis Path Diagram of the Attitude Scale towards Physics Lessons

\subsection{Results of Reliability}

The Cronbach-alpha reliability coefficients are calculated to assess the reliability of the factors of the developed scale. A Cronbach-alpha value between 0.60 and 0.70 is evaluated as sufficiently reliable, a value between 0.70 and 0.90 is evaluated as highly reliable and a value which is 0.90 and over is evaluated as very-highly reliable (Özdamar 2016). The Cronbach-alpha reliability coefficients and evaluations of the scale factors are given in Table 5.

Table 5. The reliability coefficients and evaluations of the factors

\begin{tabular}{lll}
\hline Factors & Cronbach-alpha & Evaluation \\
\hline Interest & 0.881 & High \\
Anxiety & 0.906 & Very High \\
Importance & 0.898 & High \\
Self-Efficacy & 0.707 & High \\
\hline
\end{tabular}

\section{Discussion}

In this study, an Attitude Scale towards Physics Lessons was developed for high school students (ASPL). The items of the scale, which it was decided would be a Likert scale, were developed by evaluating the opinions of high school students. The data that were gathered by applying this scale to 698 individuals were analyzed by exploratory factor analysis. As a result of this analysis a factor structure that consists of 28 items and 4 factors was formed. Confirmatory 
factor analysis was carried out for the model fit of this structure and it was found that the data of the scale were in consistent with the model. The construct validity of the scale was asserted by exploratory factor analysis, the reliability of the factors were calculated by the Cronbach-alpha coefficient and it was observed that the scale provides very high reliability for the anxiety factor and high reliability for other factors. The interest factor consists of 10 , the anxiety factor consists of 8, the importance factor consists of 6 and the self-efficacy factor consists of 4 items. The reason that the self-efficacy factor has a lower reliability compared to the others is because this factor has fewer items. Necessary studies can be undertaken to further strengthen this factor in subsequent research.

When compared with the scales developed towards physics lessons and topics, ASPL maintains distinctness within the body of literature in terms of its extent, factors and appropriateness for high school students. In terms of their scope, in the physics attitude scales developed by Kurnaz and Yiğit (2010) and Tekbiyık and Akdeniz (2010), as well as the attitude items aimed at physics lessons, there are also items aimed at the field of physics as a whole. This study has tried to ensure that the ASPL consists of items that are only directed towards physics lessons and that the extent of this scale remains physics lessons alone. When compared in terms of factors, in the Physics Attitude Scale that was developed by Kurnaz and Yiğit (2010) it can be seen that there are three factors which take the form of 'valuing physics', 'making physics habitual' and 'point of view towards physics'. The factor of 'giving importance to physics' in their scale resembles the importance factor of the ASPL but it is entirely different in terms of its item contents. The Physics Attitude Scale developed by Tekbiylk and Akdeniz (2010) consists of 30 items and 4 factors. The factors are named importance, comprehension, necessity and interest. The interest and importance factors in this scale have the same names as two of the factors in the ASPL. Though the items in the interest factor resemble those in the ASPL, the importance factor includes items that place importance mainly on physics and are therefore different from the importance factor in the ASPL. The Attitude Scale towards Simple Electric Circuits Subject developed by Taşlidere and Eryllmaz (2012a) consists of 24 questions and 5 factors. The factors of this scale are interest, importance, interest related behavior, achievement-motivation, and self-efficacy. In terms of naming the ASPL factors, it provided some benefit in regard to the interest, importance and self-efficacy factors. Although there are some similar items when the items that constitute these factors are compared it can be seen that they consist of different items. The Attitude Scale towards Optics Lessons developed by Kaya Şengören and others (2006) consists of 43 items and 3 factors. The factors of the scale are liking, fear and valuing. The fact that there is a factor named 'fear' in this scale creates a distinctness when compared to other scales. Although the factor of fear in this scale reminds us of the anxiety factor in ASPL, it is quite different in terms of its items. The biggest difference is that in ASPL the anxiety factor has a strong position within the scale. In creating an item pool for ASPL, the scale drew only on the opinions of high school students and no item was added from the body of the literature. Thus, it was ensured that the scale is only aimed at high school students.

ASPL can be used in further research to determine the attitudes of high school students towards physics lesson. With the results that will be attained, research can be carried out into the reasons why the students have these attitudes. ASPL is also a valid and a reliable scale that can be used in experimental studies in which changes in attitudes are investigated.

\section{References}

Akyüz, V. (2004). The effects of textbook style and reading strategy on students' achievement and attitudes towards heat and temperature. Unpublished Master thesis. Ankara: Middle East Tecnical University.

Atik, A. D., Kayabaşı, Y., Yağcı, E., \& Erkoç, F. Ü. (2015). The secondary school students biology science and course attitude scale: analysis of reliability and validity. Mehmet Akif Ersoy University Journal of Education Faculty, 36, $1-18$.

Azar, A., Presley, A. İ., \& Balkaya, Ö. (2006). Effect of multiple intelligence theory based instruction on students' achievement, attitude, retention, and process skills. Hacettepe University Journal of Education, 30, 45-54.

Baran, M., \& Maskan, A. K. (2009). The effect of project based learning approach on the second year's pre-service physics teachers' atitudes towards electrostatics. Dicle University Journal of Ziya Gökalp Faculty of Education, 12, $41-52$.

Bennett, J. (2001). The development and use of an instrument to assess students' attitude to the study of chemistry. International Journal of Science Education, 23(8), 833-845. http://dx.doi.org/10.1080/09500690010006554

Bilgin, I. (2006). The Effects of Hands-On Activities Incorporating a Cooperative Learning Approach on Eight Grade Students' Science Process Skills and Attitudes toward Science. Journal of Baltic Science Education, 1 (9), $27-37$.

Bozkurt, O., \& Aydoğdu, M. (2009). A comparative analysis of the effect of Dunn and Dunn learning styles model and traditional teaching method on 6th grade students' achievement levels and attitudes in science education lesson. Elementary Education Online, 8(3), 741-754.

Büyüköztürk, Ş. (2002). Factor analysis: basic concepts and using to development scale. Educational Administration: 
Theory and Practice, 32, 470-483.

Büyüköztürk, Ş. (2016). Sosyal Bilimler İçin Veri Analizi El Kitabı. Ankara: Pegem Akademi.

Büyüköztürk, Ş., Kılıç Çakmak, E., Akgün, Ö. E., Karadeniz, Ş., \& Demirel, F. (2009). Bilimsel Araştırma Yöntemleri. Ankara: Pegem Akademi.

Büyüköztürk, Ş., Kılıç Çakmak, E., Akgün, Ö. E., Karadeniz, Ş., \& Demirel, F. (2009). Scientific Research Methods. Ankara: Pegem Akademi.

Çokluk, Ö., Şekercioğlu, G., \& Büyüköztürk, Ş. (2014). Multivariate Statistics for Social Sciences SPSS and Lisle Practices. Ankara: Pegem Akademi.

Comrey, A. L., \& Lee, H. B. (1973). A first course in factor analysis. NewYork: Academic Press.

Coşkun, R., Altunışık, R., Bayraktaroğlu, S., \& Yıldırım, E. (2015). Research Methods in Social Sciences. Adapazarı: Sakarya Publishing.

Demirci, N. (2004). Students' attitudes toward introductory physics course. Hacettepe University Journal of Education, 26, 33-40.

Ekici, G., \& Hevedanl, M. (2010). Examination of the attitudes of high school students towards biology course in terms of different variables. Journal of Turkish Science Education, 7(4), 97-109.

Hancer, A. H., Uludag, N., \& Yilmaz, A. (2007). The evaluation of the attitudes of science teacher candidates towards chemistry lesson. Hacettepe University Journal of Education, 32, 100-109.

Hogarty, K. Y., Hines, C. V., Kromrey, J. D., Ferron, J. M., \& Mumfor, K. R. (2005). The quality of factor solutions in exploratory factor analysis: The influence of sample size, communality, and over determination. Educational and Psychological Measurement, 65(2), 202-226. https://doi.org/10.1177/0013164404267287

Huyugüzel, Ç. P., \& Çavaş, B. (2014). Science Teaching. Anagün, Ş.S. \& Duban, N. (Ed.). Affective Characteristics in Science Education: Attitude and Motivation. Ankara: Anı Publishing.

Kaiser, H. F. (1974). An index of factotial simplicity. Psycmetrika, 39(1), 31-36. https://doi.org/10.1007/BF02291575

Kan, A., \& Akbaş, A. (2005). A Study of Developing an Attitude Scale towards Chemistry. Mersin University Journal of the Faculty of Education, 1(2), 227-237.

Kaya, H. (2012). An investigation into upper elementary students' attitudes towards science. European Journal of Physics Education, 3(2), 22-33.

Kaya, H., \& Böyük, U. (2011). Attitude towards physics lessons and physical experiments of the high school students. European Journal of Physics Education, 2(1), 38-49.

Kaya, Ş. S., Tanel, R., \& Kavcar, N. (2006). Development of attitude scale towards optics lessons. Pamukkale University Journal of Education, 20(20), 63-68.

Kind, P., Jones, K., \& Barmby, P. (2007), Developing attitudes towards science measures. International Journal of Science Education, 29(7), 871-893. https://doi.org/10.1080/09500690600909091

Kline, R. B. (2011). Principles and Practice of Structural Equation Modeling. New York: The Guilford Press.

Koçakoğlu, M., \& Türkmen, L. (2010). Developing a biology attitude scale. Journal of Kırşehir Education Faculty, 11(2), 229-245.

Korucuoğlu, P. (2008). Evaluation of Correlation Between Scientific Process Skills' Usage Level of Physics Teacher Candidates with The Attitudes Towards Physics, Gender, Class Level, and High School Type Which They Graduated From, Unpublished Master thesis. İzmir: Dokuz Eylül University.

Krough, L. B., \& Thomson, P. V. (2005). Studying students' attitudes towards science from a cultural perspective but with quantitative methodology: border crossing into the physics classroom. International Journal of Science Education, 27(3), 281-302. https://doi.org/10.1080/09500690412331314469

Kurnaz, M. A., \& Yiğit, N. (2010). Physics attitude scale: development, validity and reliability. Necatibey Faculty of Education Electronic Journal of Science and Mathematics Education, 4(2), 32-49.

Ministry of National Education (MoNE) (2007). Turkish High School Physics Curriculum, Ankara.

Ministry of National Education (MoNE) (2013). Turkish High School Physics Curriculum, Ankara.

Nuhoğlu, H. (2008). Development of an attitude scale for primary science and technology lesson. Elementary Education Online, 7(3), 627-639. 
Orçan, A. (2013). The effect of science-fiction stories developed by comics technique, on creative thinking skills and physics attitudes of students. Unpublished Master thesis. Ankara: Gazi University.

Osborne, J., Simon, S., \& Collins, S. (2003). Attitudes towards science: a review of the literature and its implications. International Journal of Science Education, 25(9), 1049-1079. http://dx.doi.org/10.1080/0950069032000032199

Özdamar, K. (2016). Scale and Test Development Structural Equation Modeling. Ankara: Nisan Publishing.

Özyürek, A., \& Eryılmaz, A. (2001). Factors affecting students' attitudes towards physics. Education and Science, 26(120), 21-28.

Pehlivan, H., \& Köseoğlu, P. (2010). The reliability and validity study of the attitude scale for biology course. Procedia Social and Behavioral Sciences, 2, 2185-2188. https://doi.org/10.1016/j.sbspro.2010.03.304

Pell, T. \& Jarvis, T. (2001). Developing attitude to science scales for use with children of ages from five to eleven years. International Journal of Science Education, 23(8), 847-862. http://dx.doi.org/10.1080/09500690010016111

Prokop, P., Tuncer, G., \& Chuda, J. (2007). Slovakian students' attitudes towards biology. Eurasia Journal of Mathematics, Science \& Technology Education, 3(4), 287-295.

Reid, N. (2006). Thoughts on attitude measurement. Research in Science \& Technological Education, 24(1), 3-27. http://dx.doi.org/10.1080/02635140500485332

Reid, N., \& Skryabina, E. A. (2002). Attitudes towards physics. Research in Science \& Technological Education, 20(1), 67-81. http://dx.doi.org/10.1080/02635140220130939

Seçer, İ. (2015). Psychological Test Development and Adaptation Process. Ankara: Anı Publishing.

Şencan, H. (2005). Reliability and Validity in Social and Behavioral Measurements. Ankara: Seçkin Publishing.

Şentürk, E., \& Özdemir, F. (2014). The effect of science centres on students' attitudes towards science. International Journal of Science Education, Part B, 4(1), 1-24. http://dx.doi.org/10.1080/21548455.2012.726754

Shah, Z. A., \& Mahmood, N. (2011). Developing a scale to measure attitude towards science learning among school students. Bulletin of Education and Research, 33(1), 71-81.

Streiner, D. L. (1994). Figuring Out Factors: The Use and Misuse of Factor Analysis. Canadian Journal of Psychiatry, 39(3), 135-140.

Tabachnick, B., \& Fidell, L. S. (2013). Using Multivariate Statistics. Sixth Edition, Pearson Education Limited.

Taş, E. (2015). The effects of activity and gain based virtual material on students' success, permanency and attitudes towards science lesson. Journal of Education and Training Studies, 3(5), 155-164. https://doi.org/10.11114/jets.v3i5.817

Taşlıdere, E., \& Eryılmaz, A. (2012a). Development of attitude scale for simple electrical circuits and evaluation of attitudes of students. Journal of Turkish Science Education, 9(1), 31-46.

Taslidere, E., \& Eryılmaz, A. (2012b). The relative effectiveness of integrated reading study strategy and conceptual physics approach. Research in Science Education, 42, 181-199. https://doi.org/10.1007/s11165-010-9194-1

Tavşancıl, E. (2014). Measuring Attitudes and Data Analysis with SPSS. Ankara: Nobel.

Tekbiyık, A., \& Akdeniz, A. R. (2010). Physics attitude scale for secondary school students: development, validity and reliability. Journal of Turkish Science Education, 7(4), 134-144.

Türer, B., \& Kunt, H. (2015). A Review of Relationship between Prospective Science Teachers' Attitudes towards Science Education and Their Self-Efficacy. Journal of Education and Training Studies, 3(6), 166-178. https://doi.org/10.11114/jets.v3i6.983

Zacharia, Z. (2003). Beliefs, attitudes, and intentions of science teachers regarding the educational use of computer simulations and inquiry-based experiments in physics. Journal of Research in Science Teaching, 40(8), 792-823. https://doi.org/10.1002/tea.10112

\section{Copyrights}

Copyright for this article is retained by the author(s), with first publication rights granted to the journal.

This is an open-access article distributed under the terms and conditions of the Creative Commons Attribution license which permits unrestricted use, distribution, and reproduction in any medium, provided the original work is properly cited. 